Check for updates

New York

Cite this as: BMJ 2021;372:n150 http://dx.doi.org/10.1136/bmj.n150 Published: 18 January 2021

\title{
Covid-19: Biden calls for science, vaccines, and masks
}

\section{Janice Hopkins Tanne}

President elect Joe Biden has said he would rely on science, the broad distribution of vaccines, and increased mask wearing to tackle covid-19. His presidency will begin on Wednesday 20 January.

"Science will always be at the forefront of my administration," he said. ${ }^{1}$

He promised 100 million vaccinations within his first 100 days in office and asked Americans to wear masks on federal properties and during interstate travel during that time.

Biden had proposed releasing the vaccine supplies held back by the federal government to use as second doses, and President Donald Trump has released the supplies. State governors discovered there were no stored vaccines. Biden's team said that new doses from pharmaceutical manufacturers should fill the need.

Last week Biden announced his American Rescue Plan, a \$1.9 trillion emergency legislative package to fund vaccinations, change the course of the pandemic, help families suffering from the pandemic's effects, and lead to economic recovery and racial justice. He will ask Congress to provide $\$ 160$ bn for a national vaccination programme, increased testing, and a public health jobs programme; and \$40obn for measures such as improved ventilation to allow schools to reopen and paid emergency leave so people can stay at home when they need to to reduce spread of the virus, among other measures. ${ }^{2}$

As at 17 January the US had more than 23.8 million cases of covid-19 and was approaching 400000 deaths from the disease, numbers that experts have said were an undercount. Some 3353 new deaths and more than 126 ooo admissions to hospital were reported, the New York Times said. ${ }^{3}$

Hastening vaccination is important to get ahead of the virus's spread. The highly transmissible UK variant of SARS-CoV-2 has been reported in several states, and the Centers for Disease Control and Prevention has said it was expected to become the dominant US strain by March. ${ }^{4}$

Vaccine distribution is in "chaos," said the New York Times. ${ }^{5}$ More than 30 million doses of the two approved vaccines have been distributed to states, but only about a third of them have been injected into people's arms. People across the US have reported confusion in finding a place to get the vaccine. ${ }^{5}$

Biden's rescue plan calls for a national vaccination programme with increased testing and tracing, elimination of vaccine shortages, better treatments, greater supplies of personal protective equipment, paid sick leave to reduce spread of the virus, reduction in health disparities, and investment in measures to permit the safe opening of schools, from kindergartens through to high school.

The plan calls for using the Federal Emergency Management Agency and the National Guard, a reserve component of the US army and air force, to build covid-19 vaccination clinics across the country and to make vaccines widely available through pharmacies. The National Association of Chain Drug Stores said it could administer at least 100 million doses of vaccine each month. ${ }^{6}$

Biden's plan relies on science. He named Eric Lander, a leader of the Human Genome Project and head of the Broad Institute of the Massachusetts Institute of Technology and a Harvard director, as his top scientific adviser and raised the position to cabinet level.

Among other science appointments, Biden confirmed Francis Collins to continue as director of the National Institutes of Health, named former FDA head David Kessler to lead the covid-19 response, and California attorney general Xavier Becerra to head the Department of Health and Human Services, replacing Alex Azar, who is resigning. Rochelle Walensky, chief of infectious diseases at Massachusetts General Hospital and professor of medicine at Harvard, was appointed to head the Centers for Disease Control and Prevention.

1 Mucha S. Biden elevates White House science post to cabinet level. CNN. 15 Jan 2021. https://www.cnn.com/2021/01/15/politics/eric-lander-whitehouse-science-cabinet/index.html.

2 President-elect Biden announces American rescue plan. https://buildbackbetter.gov/wp-content/uploads/2021/01/COVID_Relief-Package-FactSheet.pdf.

3 Coronavirus in the US: latest map and case count. New York Times. 17 Jan 2021. https://www.nytimes.com/interactive/2020/us/coronavirus-us-cases.html.

4 Galloway SE, Paul P, MacCannell DR, etal. Emergence of SARS-CoV-2 B.1.1.7 Lineage - United States, December 29, 2020-January 12, 2021. MMWRMorb Mortal Wkly Rep2021;15. doi: 10.15585/mmwr.mm7003e2.

5 The next president actually has a covid plan. New York Times. 16 Jan 2021 https:/www.nytimes.com/2021/01/16/opinion/coronavirus-biden-vaccinecovid.html.

6 Lovelace B. Biden to deploy FEMA, National Guard to set up covid vaccine clinics across the US. CNBC. 15 Jan 2021. https://www.cnbc.com/2021/01/15/biden-to-deploy-fema-national-guard-to-set-up-covidvaccine-clinics-across-the-us.html. 